\title{
The Stakeholders' Role in Sustaining Renewable Energy Systems in Sumba Island
}

\author{
Niken PRILANDITA, School of Architecture, Planning and Policy Development, Bandung \\ Institute of Technology; Indonesia \\ Saut SAGALA, School of Architecture, Planning and Policy Development, Bandung Institute of \\ Technology; Indonesia \\ Teresa ARSANTI, Resilience Development Initiative, Indonesia \\ Jeeten KUMAR, Resilience Development Initiative, Indonesia
}

\begin{abstract}
Sumba Iconic Island is a collective program established by the national government through the Ministry of Energy and Mineral Resources (ESDM) with various governmental and international institutions such as the National Electricity Company (PLN), Hivos, Norwegian Embassy in Jakarta, Asian Development Bank, and all level of local government from provincial, regency, municipality, district, and village level. This paper focuses on using qualitative data gained through interviews with stakeholders to find out the various operation and maintenance models of renewable energy power plants that are currently in practice in Sumba Island.

This study shows that currently there are four models of operation and maintenance for systems throughout numerous villages in Sumba. The first one describes O\&M being handled by trained locals, second one is handled by the village cooperative (Koperasi), the third one is collaboration between PLN and local government units or private sector, and the last one is collaboration with the private sector and village-own company (BUMDes). The first one mentioned is the weakest one, and faced many constraints such as lack of technical skill and the local peoples' limited understanding. The other three models succeeded, to a certain extent, in sustaining the renewable energy system in the particular village.
\end{abstract}

\section{Keywords}

Operation and maintenance, renewable energy, power plant, Sumba Island

\section{Introduction and Aim}

Sumba island is one of the least-developed regions in Indonesia with issues revolve around poverty, minimum infrastructure as well as lack of social services. Located in the impoverished Province of Nusa Tenggara Timur (NTT), more than $30 \%$ of the island's population are in poverty according to 2016 statistical data documented by Indonesia Statistical Bureau. Transportation infrastructure and facilities are still very limited in terms of 
quantity, quality and frequency of flights. Village access roads are often in poor condition, with loose stones and potholes. Roads are not all paved, or sometimes only paved with sand and stones. Roads between sub-villages are generally unpaved. Markets are generally further away and there are fewer kiosks in villages. Next, the regencies in Sumba (specifically in West Sumba) has the highest number of neglected children under 5 years old (Indonesia Statistical Bureau, 2016) which indicates the severe absence of social services there. Limited numbers of schools contributed to the high rate of illiterate particularly among women. Health facilities are mainly found in sub-district towns, due to limited availability of doctors.

One of the barriers of development in Sumba is the lack of electricity. More than up to $60 \%$ of the families in Sumba live without electricity (Indonesia Statistical Bureau, 2017). A Study conducted by Craine (2013) reported that at the national level, while $72 \%$ of the country has grid electricity from PLN, only $6 \%$ of the country is using kerosene lighting. Surprisingly, half of this $6 \%$ population are situated in NTT with approximate numbers of $50.000-60.000$ households. Sumba has two main grid systems, Waikabubak and Waingapu. The peak load of the Waingapu and Waikabubak systems combined amount to about $5.5 \mathrm{MW}$ with a $2.5 \mathrm{MW}$ base load. The energy demand on this sparsely electrified island is increasing in line with regional economic development and population growth. Based on PLN information, the electricity demand in Waingapu and Waikabubak has grown with $6 \%$ and $8 \%$ per year respectively.

Due to its poor condition, the island has been one of the main development agendas for the Government of Indonesia (Gol) in the last 5 years. As a way to respond to the needs for energy and electricity many entities including government institutions have tried to harness renewable energy technology as alternatives. Overall, Sumba poses as the ideal candidate for the 'fossil fuel independent pilot island.' Important renewable energy resources, such as Hydro, solar, wind and biogas are present on the island and have high potential in terms of becoming the primary energy sources for the island. The Gol through its National Electricity Company (PLN) has provided a huge number of solar lighting sets for villagers that currently do not have access to the main power grid. The villagers pay a small fee to participate in the programme and in return PLN maintains and repairs the lighting sets.

A more integrated initiative has been started involving multi background stakeholders from the government to NGO in a program called Sumba Iconic Island (SII). This program is coordinated by the Indonesian Ministry of Energy and Mineral Resources (MEMR), together with Hivos, since 2010. By maximizing the potential of renewable energy particularly on biogas, biomass, solar, hydro, and wind energy in Sumba; to date, the program has successfully produce RE installation that contributes to $20.9 \%$ out of the total of $50.9 \%$ of Sumba's current electrification ratio, covering electricity access to 4158 households and 14.868 solar powered plants (Herdiani, 2018).

The SIl targeted that Sumba Island is going to be $100 \%$ electrified by 2020 . However, to date, the electrification ratio has only reached $50.9 \%$ (EBTKE, 2018), from all types of systems. This number is actually has been doubled since the project started in 2010. The problem that frequently faced by the RE system installed in Sumba villages are happened in the Operation and Maintenance phase. Therefore, this paper aims to identify the O\&M mechanisms 
existed in RE system in Sumba, and also tries to understand the stakeholders' role, particularly in the O\&M phase

\section{Methodology}

The method used in this paper is descriptive qualitative, we attempted to describe various O\&M processes in the off-grid renewable energy systems in Sumba Island. The organizational structures for maintenance work is described chronologically based on the stakeholders' role. In particular, we focused on issues relating to the operation and maintenance of various off-grid renewable energy systems in rural areas and whether any level of synergy exists, or should exist, between public and private actors.

The field survey employed a qualitative approach as the primary means of collecting and analyzing the data. In order to gain a deep and thorough understanding of the various models of operation and maintenance in off-grid RE power plants in Sumba Island, data was gained through in-depth key informant interviews and focus group discussions, where respondents were subject to semi-structured interviews and discussions, with questions that were framed to consider about their experience and invite them to reflect on additional information that they find pertinent. Respondents include technicians, village leaders, community members, representatives of NGO/INGOs in the region, and public officials. The recorded interviews and conversations were transcribed and underwent content and descriptive analyses. The list of interviewees are further described in Table 1.

Table 1 List of Interviewees in Sumba Island

\begin{tabular}{|c|c|c|c|c|}
\hline Village Name & NGOs & INGOs & Government Agencies & Private Business \\
\hline Ndinjo & IBEKA & Hivos & $\begin{array}{l}\text { Regional Planning and } \\
\text { Development Agency }\end{array}$ & $\begin{array}{l}\text { PT. RESCO Sumba } \\
\text { Terang }\end{array}$ \\
\hline Analewe & & & $\begin{array}{l}\text { State Electrical Company } \\
\text { (PLN) }\end{array}$ & \\
\hline \multicolumn{5}{|l|}{ Dangga Mango } \\
\hline \multicolumn{5}{|l|}{ Weepaboba } \\
\hline \multicolumn{5}{|l|}{ Odi Praurata } \\
\hline \multicolumn{5}{|l|}{ Weelimbu } \\
\hline \multicolumn{5}{|l|}{ Kanilu } \\
\hline \multicolumn{5}{|l|}{ Lete Kamauna } \\
\hline \multicolumn{5}{|l|}{ Tebara } \\
\hline \multicolumn{5}{|l|}{ Djela Manu } \\
\hline \multicolumn{5}{|l|}{ Rada Loko } \\
\hline Ramadana & & & & \\
\hline
\end{tabular}

The contents of the table shows that most of the key informants are village leaders from 12 villages in West and Southwest Sumba. The village leaders were able to give us firsthand 
details regarding renewable energy power plants that were constructed in their village, based on their own experiences, observations, or correspondence with other locals. Due to the close proximity between the villagers and the power plants, village leaders often converse with outside technicians or volunteers that operate or maintain the power plant. NGO/INGOs interviewees are from IBEKA and Hivos respectively. IBEKA and Hivos are responsible for developing and constructing renewable energy technology power plants throughout Sumba, including wind farms, micro hydro plants, and solar PV farms, as well as each of their corresponding off-grid power lines. Officials from the Regional Planning and Development Agency (Bappeda) and State Electrical Company (PLN) were interviewed to gain information on the inner workings of managing a renewable energy power plant and whether any regulation or statutes exist that governs or constrains such activities. Lastly, PT. RESCO Sumba Terang is a private company that has also been involved in the construction and design of several solar PV power plants, in collaboration with Hivos and BIRU among others.

\section{Results and Analysis}

The results of our field data collection indicates that there are four operation and maintenance (O\&M) models currently in practice by multiple off-grid renewable energy plants spread throughout Sumba Island. This information was gained primarily from our focus group discussion held in the Regional Planning and Development Agency in East Sumba, attended by public officials, representatives of INGOs that play a role in the renewable energy development in the region, as well as representatives from academia and communities.

The four O\&M models that are currently in place are distinguished based on who operates and maintains the power plant, as follows: (1) the local community where the power plant is located and to whom it serves; (2) locally organized cooperative, in which members of the community band together to manage the power plant as a locally owned enterprise; (3) the State Electricity Company (PLN), the state-owned enterprise that serves and provides on-grid electricity for the region; (4) private sector/developer model, which take form as national or international NGOs (Gah, 2018). The results suggest that despite the ubiquity of renewable energy power plants in the island, there currently isn't a mutually agreed policy or structure that governs the process of maintenance for the disparate models. The stakeholders for the power plants in each respective O\&M model are then tasked with determining the best maintenance process for their power plants based on the assets that are accessible to them.

\subsection{Operation and Maintenance by the local community}

There are several local communities who operate and maintain the renewable energy power plant, namely the communities in Ndinjo, Analewe, Dangga Mango, Weepaboba, Odi Praurata, Weelimbu, Kanilu, and Lete Kamauna Villages. These villages have two accessible sources of electricity which are on-grid, connected to the state electrical grid from PLN; and off-grid, that is connected to the solar PV. The solar PV serves as an auxiliary electrical source provided through the joint efforts of the local government, village government, and 
PLN. However, the same actors decided in unison that the technology is used and operated by the community, hence once the handover was completed, the process of operation and maintenance are handled by the community.

Based on our observation, there are at least two sub-models of operation and maintenance practiced by the communities. First, the sub-model in which maintenance processes were directly conducted by the solar PV end-user. Second, the sub-model in which maintenance processes are handled by an appointed local that was subsequently trained as a technician by PLN staff and aided by a local handyman that serve to repair the solar PV of the village. However, the case of village technician or local handyman that handle the O\&M process is only implemented in 2 out of 8 villages that we visited, namely in Odi Praurata and Kanilu Villages. There were 2 O\&M technicians in Odi Praurata, these technicians were trained by PLN staffs when they handed over the solar PV to the community (Yulius, 2018). Meanwhile in Kanilu village, the 2 local handymen were chosen due to their experiences (Wilem, 2018).

There are both similarities and differences of O\&M process between the villages that have the first and second sub-model of O\&M. The similarity between these two O\&M sub-models is that the end users operate and maintain the solar PV independently on their own during its average lifespan of 2 years. Meanwhile, the difference lies on the maintenance aspect when the solar PV is damaged. The maintenance processes of the two sub-models community O\&M, when the solar PV is damaged, are different. The maintenance process of the first sub-type of community O\&M is handled by the end-users themselves. Meanwhile, the community relies on the technician's assistance on the second sub-type of community O\&M. The community tends to bring the damaged solar PV to the technicians or local handymen to be fixed.

These two sub-models of community O\&M have similar problems since most of the O\&M process is handled by the end-users. These problems are (i) the lack of local community's capacity; (ii) the financial issues; and (iii) the lack of security (Gah, 2018). First, the lack of local capacity leads to the unsustainable O\&M process within the community. As an example, the community directly utilizes and connects the solar PV into the phone battery. Because of that, there lies the possibilities for the phone battery to explode, be damaged, and harm the solar PV itself. Another example, especially in the first sub-model of O\&M, a tendency to either leave the damaged solar PV alone or fix the damaged solar PV without appropriate knowledge of the end-users is high. Therefore, the damaged solar PV can't be fixed properly and further increase the problems within the solar PV. In consequence, the community tends to abandon then throw away the damaged solar PV and decide to re-use the Pelita. Second, the financial issue also affects the community not to repair any damaged solar PV because the community should pay for the service that is provided by the technicians. The community has not been able to structure and manage the budgeting. Last, the problem regarding the security. Several parts of the power plants are found missing because there is a lack of security. As the renewable energy power plant is managed by the community, the possibility that the power plant is being left without any monitoring system is high. Therefore, it could increase the possibilities that lead to the theft of the power plant (Gah, 2018). 


\subsection{Operation and Maintenance by Cooperative}

Cooperative acts as the entity that operates and maintains the renewable energy power plant. Based on our interview with IBEKA, one of the cooperatives that manages to work on the O\&M process is Kenyulururi Cooperative. Kenyulururi Cooperative is in charge for the daily operation of Kamanjara Micro Hydro Power Plant (MHPP) in Moubokul. This MHPP was constructed on November 12, 2017 by Ibeka (Institut Bisnis dan Ekonomi Kerakyatan), a social business entity with engineering focus. It has been operated for 9-10 months (per March 2019). The installed capacity of this MHPP is $95 \mathrm{~kW}$ (65kW based on Ibeka website) and it supplies electricity for 106 households in Moubokul Village. The daily operation of this MHPP is handled by the Kenyulururi Cooperative as it hires the operator to ensure the daily operation of the MHPP. However, shall any part of this MHPP is damaged, the operator will report to Ibeka and Ibeka will further replace the broken part. Ibeka still holds the responsibility for the MHPP as the asset has not fully transferred to the village government (Petrus, 2018).

Regarding the information from Bappeda, the O\&M process that is controlled by the collaboration with the cooperative could be classified as quite successful. One of the reasons of the quite successful O\&M Process is the cooperative conducted the training support in collaboration with the Ministry for the technician to operate and maintain the renewable energy power plant. Hence, in the event that the transfer assets has been conducted and the cooperative has to manage the whole O\&M process, the cooperative has already been prepared, through the training, to handle the O\&M process (Gah, 2018).

\subsection{Operation and Maintenance by PLN}

The third model of O\&M is handled by PLN, a state electricity company in Indonesia. PLN is the main actor that administers the electricity supply business in adequate amount and quality. PLN could provide the electricity supply from renewable energy power plant for the end-users by constructing the power plant or transferring the assets from the previous holder. Subsequent to the ownership of renewable energy power plant by PLN, PLN will control the O\&M process of its assets. Besides that, PLN had run the assets belonged to third parties such as MHPP in Waekelo Sawah, MHPP in Kamanggih, Billa Cenge Solar Power Plant (SPP), and Bodohula Biomass Power Plant (BPP) (DAGI Consulting, 2018).

MHPP in Kamanggih could be referred to as one of the examples how PLN manages the O\&M process. MHPP in Kamanggih was built in 2011 by lbeka in cooperation with Hivos. Once the power plant was officially operating, the O\&M process was handled by Jasa Peduli Kasih Cooperative. Subsequent to the 2 years O\&M process handled by the cooperative, in 2013, the management of this MHPP was handed over to PLN after the interconnection cooperation agreement was being signed. The cooperative is now selling the electricity not to the end-users directly, but to the PLN with the rate of Rp475/kWh. PLN handles the management of MHPP including the maintenance, distribution of electricity, and bills due from household users. PLN is also hiring technicians to operate the MHPP in Kamanggih. Every month, the cooperative will submit the billing to PLN in relevance with the electricity usage per month and will earn the income from the electricity sales (Bakti Foundation, 2016). Despite of the existing collaboration, there is one big challenge occurs in the O\&M process, namely the transfer of assets between the asset owner and PLN. If the transfer of 
assets hampers the whole process of cooperation, there might be possibilities that PLN will stop the O\&M process, as happened in the case of MHPP Wakaleo Sawah (DAGI Consulting, 2018). But overall, based on the statement from Bappeda, PLN has conducted the O\&M process well in the professional way (Gah, 2018).

\subsection{Operation and Maintenance by Private Sectors}

The last model of O\&M is handled by the private sector in collaboration with BUMDes. In the case of East Sumba, the solar PV installation, with 11 microgrid solar panels, has electrified 5 villages, namely Tawui, Lailunggi, Praimadita, Tandula Jangga, and Praiwitu Village since April 2018. The solar PV has the total capacity of $492 \mathrm{kWp}$ and be able to supply the electricity for 852 households and 57 public facilities (MCA-Indonesia, 2018). The project is funded by the United States of America under the grant from MCA-I.

The collaboration between the private sector and BUMDes is working under the certain scheme, (i) the BUMDes in each village establish the joint BUMDes (BUMADes), (ii) the joint BUMDes creates a company in the form of PT (Perseroan Terbatas/Limited Liability Company, (iii) the company owned by these BUMDes is collaborating with the project developer, PT. Mikro Kisi Sumba (MKS). The profit sharing from the scheme is $51 \%$ for the BUMDes and $49 \%$ for the project developer (Gah, 2018). In order to ensure the sustainability aspect of this project, the 5 established BUMDes in the villages (52 management members) had received the management and entrepreneurship training (MCA-Indonesia, 2018). PT. Mikro Kisi Sumba acts as the holder of WUPTL (Wilayah Usaha Penyediaan Tenaga Listrik). For the O\&M process and main distribution network are handled by PT. Listrik Vine Industri, meanwhile the minor O\&M is handled by the BUMDes. Besides that, Hivos has also established a renewable energy service company, PT. RESCO Sumba Terang that is focusing on the O\&M process for the renewable energy facilities built by Hivos and funded by MCA-I (DAGI Consulting, 2018). Based on the statement of Bappeda, the private sector O\&M process is well conducted by developer. It has also increased the participation rate of BUMDes, village government, and the community to preserve the renewable energy power plant (Gah, 2018).

\section{Discussion and Concluding Remarks}

Based on the information gathered through interviews, focus group discussion, and direct observation, there are currently four O\&M models existed for communal renewable energy system in Sumba Island. The first model which solely relies on the local community, both the end user and the appointed local technician, faced huge challenges in maintaining the system. The lack of capacity of the local community and financial issues are consistently came up in the models that use local community for the system's O\&M. Whereas the other three models are able to sustain their O\&M phase up until present time.

It is worth pointing out several limitations in our study, particularly those that are present in the methodology. Firstly, the analysis is limited in both scope and time. The number of respondents through whom we were able to acquire data were not sufficient to represent all off-grid renewable power plants in Sumba Island and their respective technologies. The time they were afforded was also limited due to their other obligations at the time. Secondly, due 
to the disproportionate number of technologies represented by the respondents, we therefore contrived to categorize all manner of RE technologies like solar, wind farms, micro hydro, and biogas, among others, under one umbrella term: renewable energy power plants. We recognize that by doing so, we inadvertently generalized issues or complexities unique to a certain set of technologies for the sake of simplicity.

This early study has shown that in order to sustain the O\&M phase of renewable energy system in Sumba, the involvement of the third party is still needed. Furthermore, since the capacity of the local community is relatively low, the regular training is not sufficient to enhance their skill. There is a need for a more intensive training to prepare the locals for this phase. The result also shown that it is possible for the local community to do the O\&M phase for sustaining the RE systems in their village as long as that the collaboration with other party is well established.

\section{References}

Bakti Foundation. (2016). BaKTINews Memahami KTI dengan Seksama. Makassar, Indonesia: Bakti Foundation. Retrieved from http://bakti.or.id/sites/default/files/files/baktinews/BaKTINews126.pdf

Dagi Consulting. (2018). Monitoring \& Evaluasi Program Sumba Iconic Island 2018. Jakarta: Dagi Consulting.

EBTKE. (2018, October 25). Direktorat Jenderal Energi Baru Terbarukan dan Konservasi Energi. Retrieved from Revitalisasi Program Sumba Iconic Island Sebuah Solusi Atas Sumba: http://ebtke.esdm.go.id/post/2018/10/25/2040/revitalisasi.program.sumba.iconic.i sland.sebuah.solusi.atas.evaluasi?lang=en

Gah, Y. (2018, March 27). Secretary of East Sumba Regency Bappeda. (RDI, Interviewer)

Herdiani, I. A. (2018, April 02). Head of ANEKA EBTKE Cooperation Section. (T. R. Arsanti, N. Prilandita, S. Sagala, J. Lovett, K. Li, \& Y. Prambudia, Interviewers)

MCA-Indonesia. (2018, April 11). Millenium Challenge Indonesia. Retrieved from Akses Listrik Bersig 500 kWp untuk Desa-Desa Terpencil di Sumba Timur: http://www.mcaindonesia.go.id/id/our_news/press_releases/new_access_to_about_500_kwp_of_cl ean_energy_for_remote_villages_in_east_sumba-1268

Petrus. (2018, March 26). Technician of IBEKA. (J. Kumar, RDI, Interviewer)

Wilem. (2018, March 23). Head of Kanilu Village. (T. R. Arsanti, \& R. M. Nurdiandra, Interviewers)

Yulius. (2018, March 23). Head of Odi Praurata Village. (T. R. Arsanti, \& R. M. Nurdiandra, Interviewers) 